\title{
Pan-RAF Inhibitor LXH254
}

National Cancer Institute

\section{Source}

National Cancer Institute. pan-RAF Inhibitor LXH254. NCI Thesaurus. Code C125003.

An orally available inhibitor of all members of the serine/threonine protein kinase Raf family, with potential antineo plastic activity. Upon administration, pan-RAF inhibitor LXH254 binds to Raf proteins and inhibits Raf-mediated signal transduction pathways. This inhibits proliferation of Raf-overexpressing tumor cells. Raf protein kinases are critical enzymes in the Ras/Raf/MEK/ERK signaling pathway and are upregulated in a variety of cancer cell types. They play key roles in tumor cell proliferation and survival. 